\title{
Reviewing the Effect of 10 Days of Intense Exercise Period on Certain Blood Parameters of Tennis Players
}

\author{
Muzaffer Selcuk ${ }^{1}$, Vedat Cinar $^{2}$, Mucahit Sarikaya ${ }^{1}$, Salih Oner $^{1}$ \\ ${ }^{1}$ Van Yuzuncu Yil University, School of Physical Education and Sports, Van 65080, Turkey \\ ${ }^{2}$ Frrat University, Faculty of Sports Sciences, Turkey \\ Correspondence: Muzaffer Selcuk, Van Yuzuncu Yil University, School of Physical Education and Sports, Van 65080, \\ Turkey.
}

Received: August 20, 2018

doi:10.11114/jets.v6i11.3469
Accepted: September 13, $2018 \quad$ Online Published: September 16, 2018

URL: https://doi.org/10.11114/jets.v6i11.3469

\begin{abstract}
This study aims to observe the possible negative effects that might occur on bio-chemistry and hemogram values of tennis players during the intense competition period by comparing the blood values of pre-competition period with 10 days of intense exercise. Blood samples were obtained from tennis team players who do not have any specific health problems and who study in university and regularly exercise. Mean age of the athletes are 22,40 $\pm 3,20$ years and mean height is $179,83 \pm 7,57 \mathrm{~cm}$. This study is performed with 14 volunteer tennis players. Blood samples are obtained during the first day of the intense exercise program after the exercise, last day of the exercises and also right after the exercises. As per the obtained data, descriptive statistics are run (mean and standard deviation) and in order to compare the values of before and after the 10 days of intense exercise, Wilcoxon two related sample test was used. As per the results of the blood tests from before and after the exercise period, it is seen that values such as AST, ALT, MCH, MCHC and CK showed statistical significance $(\mathrm{P}<0.05)$. The athletes who prepared for the competitions with these values showed positive increases in bio-chemistry and hemogram values.
\end{abstract}

Keywords: muscle damage, tennis, interval exercises

\section{Introduction}

Nowadays, tennis is an Olympic sports branch which is embraced by the contemporary world and which is an exciting sport to perform a s well as to watch, not to mention the awe that it brings for the ones who do. This branch of sports is a performance sport which combines aerobic (such seen in handball, football and volleyball) and anaerobic loadings as well as requiring a good level of biomotoric skills such as force, velocity, stamina, flexibility and coordination (Ozer et al. 2017; Pancar, 2015; Pancar et al. 2018; Ferrauti et al. 2002; Pancar et al. 2017; Kermen, 1997). In that sense, tennis is one of sports branches which require advanced physical compatibility. For a tennis player to make effective shots, he/she would need to hold all physical compatibility parameters in high levels. As it is game with no competitive contact, it requires to have rapid change of directions, rapid arm movements, an advanced reaction time, jumps and moves (Pancar et al. 2016; Chu, 1995; Gullikson, 2003; Weber, 1982). For this reason, in tennis, it is a must to have strong muscles which generate the force, as well as to have high levels of anaerobic and aerobic power (Ferrauti et al. 2002; Chu, 1995; Zorba, 1993). Undoubtedly, improving these attributes with effective exercises (Vural et al. 2017), would positively affect the athlete's overall success. Fundamentally, the expectations of athletes from exercises are focused on the goal of optimizing the performance.

On the other hand, physical compatibility values of athletes which include physical, physiological and anthropometric attributes are utterly important in talent selection. In order to achieve high performances in national and international tennis competitions, branch-specific physical requirements and the capacity of athletes and teams to meet with these requirements need to be evaluated. Hence, it is vital to evaluate the combination of technical and tactical skills with physical form in order to reach optimal performance. Additionally, Hoare points out that talent selection programs of physical and physiological attributes focus on individual sports and not uttered much when it comes to team sports (Hoare 2000). In that context, it is seen that tennis, as a popular contemporary sports branch, is outstanding with the fact that it is both an individual and a team sport, creating an important appeal in sports participation. In order to develop this quality and to accelerate the process, talent selection and improving this talent is extremely important in tennis. From this point on, the aim of this study is to review the effect of 10 days of intensive exercises with loading techniques of repetition, intensive (mainly) and extensive interval methods on blood parameters. 


\section{Method}

The study is performed with 14 volunteer tennis players with no health problems, who study in university and do exercises regularly 4 times a week - with mean age of 22,80 $\pm 3,20$ years, mean height of 185,83 $\pm 7,57 \mathrm{~cm}$ and mean weight of $77,46 \pm 9,31 \mathrm{~kg}$.

The blood samples obtained from the athletes, which are drawn after the first day of the intense exercises (15 minutes) and after the 10th day's exercise (15 minutes), are analyzed in lab environment with CELL-DYN-3500 R automatic blood test device in $5 \mathrm{~mm}$ tubes with EDTA. The analysis of the obtained data is done with SPSS program package. Wilcoxon two related sample test is used to compare the values from before and after competitions with descriptive statistics.

The study mainly includes repetition, intensive (mainly) and extensive interval methods during the 10 days of exercises before competition. Additionally, branch-specific intense technical exercises and drills supporting technical motions are used. In loading intervals, less repetitive intensive exercises, which is the most severe of repetitive loading method, are used. In resting intervals, full resting, submaximal exercises with mid level repetitions within intensive loading method are applied and efficient resting is perfomed during intervals. Loadings including extensive interval method are applied comprehensively. In resting intervals, efficient resting is used. It is specifically cared to do the exercises with highest possible efficiency and for that purpose the athletes are constantly encouraged.

Table 1. Bio-chemistry values

\begin{tabular}{lllll}
\hline Variables & $\begin{array}{l}\text { N=10 } \\
\text { Before }\end{array}$ & After & Z & P \\
\hline ALT & $23,857 \pm 9,63$ & $19,00 \pm 4,69$ & $-2,286$ & $\mathbf{, 0 2 2} *$ \\
AST & $26,21 \pm 6,62$ & $22,50 \pm 5,06$ & $-2,312$ & $\mathbf{, 0 2 1 *}$ \\
AMY & $76,57 \pm 26,6$ & $74,92 \pm 21,08$ &,- 377 & $\mathbf{, 7 0 6}$ \\
BíLD & $33,14 \pm 10,67$ & $22,61 \pm 7,86$ & $-2,748$ & $\mathbf{, 0 0 6} *$ \\
CaC & $98,57 \pm 3,13$ & $96,64 \pm 3,10$ & $-1,606$ & $\mathbf{, 1 0 8}$ \\
CK & $198,14 \pm 81,74$ & $148,71 \pm 51,93$ & $-2,668$ & $\mathbf{, 0 0 8 * *}$ \\
NaC & $139,92 \pm, 99$ & $139,85 \pm 1,61$ &,- 159 & $\mathbf{, 8 7 4}$ \\
KC & $41,92 \pm 4,37$ & $42,14 \pm 5,11$ &,- 070 & $\mathbf{9 4 4}$ \\
CIC & $105,71 \pm 1,32$ & $105,35 \pm 1,54$ &,- 920 & $\mathbf{, 3 5 7}$ \\
CreaC & $88,07 \pm 13,03$ & $83,64 \pm 12,08$ & $-1,468$ & $\mathbf{1 4 2}$ \\
GluC & $90,50 \pm 6,53$ & $91,21 \pm 5,16$ &,- 314 & $\mathbf{, 7 5 3}$ \\
Phos & $33,92 \pm 4,39$ & $37,71 \pm 3,77$ & $-1,953$ & $\mathbf{0 5 6}$ \\
Urea & $31,78 \pm 6,60$ & $31,71 \pm 6,67$ &,- 079 & $\mathbf{, 9 3 7}$ \\
\hline
\end{tabular}

\section{Findings}

Significant decreases are observed in CK, AST, ALT, BILD, MCH, MCHC, WBC values, when the blood samples from before and after intense exercises are compared $(\mathrm{P}<0.05)$. 
Table 2. Hemogram values

\begin{tabular}{|c|c|c|c|c|c|}
\hline \multirow[t]{2}{*}{ Variables } & \multicolumn{3}{|c|}{$\mathrm{N}=10$} & \multirow[t]{2}{*}{$\mathbf{Z}$} & \multirow[t]{2}{*}{$\mathbf{P}$} \\
\hline & Before & & After & & \\
\hline WBC & $8,34 \pm 1,42$ & 8,21 & $\pm 1,17492$ & $-3,23$ &, $042 *$ \\
\hline $\mathrm{RBC}$ & $5,27 \pm, 36$ & 5,20 &, \pm 52592 &,- 699 &, 484 \\
\hline HGB & $15,35 \pm, 81$ & 14,94 & $\pm 1,40235$ &,- 942 & ,346 \\
\hline $\mathrm{HCT}$ & $46,64 \pm 2,28$ & 45,43 & $\pm 3,78186$ &,- 706 & ,480 \\
\hline $\mathrm{MCV}$ & $88,04 \pm 3,63$ & 86,93 & $\pm 4,72825$ & $-1,415$ & ,157 \\
\hline $\mathrm{MCH}$ & $28,70 \pm 1,57$ & 28,27 & $\pm 1,88514$ & $-2,12$ &, $034 *$ \\
\hline $\mathrm{MCHC}$ & $31,86 \pm 1,45$ & 32,87 &, \pm 81352 & $-2,073$ & ,038* \\
\hline RWD-CV & $12,82 \pm, 50$ & 13,18 &, \pm 74613 & $-1,69$ & ,089 \\
\hline RWD-SD & $45,70 \pm 1,71$ & 46,91 & $\pm 4,36152$ &,- 628 &, $\mathbf{5 3 0}$ \\
\hline PLT & $248,8 \pm 45,38$ & 239,11 & $\pm 68,42412$ & $-1,02$ & ,308 \\
\hline PCT &, $22 \pm, 04$ &, 21 &, \pm 05954 & $-, 1,086$ & ,277 \\
\hline MPV & $8,38 \pm, 63$ & 8,80 &, \pm 61644 & $-2,71$ & ,070 \\
\hline PDW & $17,20 \pm, 62$ & 16,76 & $\pm 2,42633$ &,- 625 &, 532 \\
\hline PLCR & $41,40 \pm 5,78$ & 43,64 & $\pm 6,21719$ & $-2,347$ & 0,19 \\
\hline $\mathrm{NE}$ & $5,08 \pm 1,22$ & 4,40 & $\pm 1,46604$ & - 1,428 & ,153 \\
\hline LY & $2,90 \pm, 46$ & 2,80 &, \pm 62723 &,- 866 & ,153 \\
\hline MO &, $59 \pm, 14$ &, 582 &, \pm 16646 &,- 237 &, 813 \\
\hline EO &, \pm 09 &, 14 &, \pm 13972 &,- 842 & 0,400 \\
\hline BA &, \pm 02 &, 07 &, \pm 02954 & $-, 1,969$ & $\mathbf{0 , 4 9}$ \\
\hline
\end{tabular}

\section{Discussion and Conclusion}

Obtained findings indicate that the intense competitions might have an effect on the physiological attributes of tennis players. The studies in literature are focused on the acute effects of exercises on blood parameters and significant increases are seen in CK, HGB, HCT, WBC, cholesterol, ALT, AST values (Pancar et al. 2017; Nieman DC and Pedersen Bk, 1999; İbiş S. et al., 2010; Skurvydas et al., 1985; Pancar et al., 2018; Novosadová J., 1977; Retallick CJ., 2007).

However, there are no adequate amount of studies in the literature on the effect of intense competition periods on blood parameters. Cinar et al. (2013) reviewed the effect of 10 days of intense competition period on blood parameters of football players and put forward that there is significant effect on RBC (Erythrocyte), PLT (Thrombocyte) and HGB (Hemoglobin) $(p<0,05)$ and statistically insignificant effect on WBC (Leucocyte) values ( $>0,05)$. This study focused on less amount of blood parameters and blood samples are drawn 2 hours later than the end of intense competitions (Gencer et al. 2018). In another study, in order to eliminate the acute effect of intense exercises, blood samples were checked after 1 day and it was seen that there is significant increase in AST, ALT, MCH, MCHC values and significant decrease in HCT and MPV values $(\mathrm{p}<0,05)$. It is found that 10 days of intense interval exercises caused significant decreases in ALT and AST values. ALT and AST values refer to liver enzymes and also they can be found in other tissues. After exercises, high levels of ALT and AST indicate intense liver functions stemming from muscle damage. As a result of the decrease in ALT and AST values due to intense interval exercises before competition and also branch-specific technical exercises, following conditions are seen to be occurred: less stress in liver which detoxifies matters related to muscle damage which is results in morphological, biochemical and physiological changes, hence regular exercises protecting the overall health of athletes, and less muscle damage. Bilirubin values are seen to be significantly decreased. The reason for this is that intense interval exercises do not cause serious decrease in blood volume and that resting intervals and the fluid support during these intervals help maintaining the high volume of blood. Another reason is that as the blood with high fluidity rate shows less amount of friction due to the lack of solid matters it causes less damage especially with red blood cells, of which the membrane is fragile. And this situation leads to a significant decrease in direct bilirubin level, proving the beneficial effect of chronic exercises.

Gencer et al., (2018), pointed out that there is significant increase in CK levels after 10 days of intense competition $(\mathrm{p}<0,05)$. Selçuk et al., (2018) in a different study, found that there is significant decrease in the pretest and posttest results experimental group after 8 weeks of exercise $(\mathrm{p}<0,05)$. CK is an enzyme of phosphocreatine metabolism. Isoforms are found in muscles, heart muscle and brain. In our study, decrease in CK level are seen to be significant. This is a change in energy metabolism depending on intense chronic exercises and this change has positive effects on phosphoylation of creatine phosphate. Also, depending on these chronic exercises there is decrease in leakage of oxygen from muscle cells and with that muscle damage decreases. Then, this causes to think that it is a normal in significant decline of CK level that is assumed as indicator of muscle damage and it depends on chronic and acute exercises. 


\section{References}

Chu, D. A. (1995). Power Tenis Training, Human Kinetics Champaign, 7(15), 33-45.

Cinar, V., Cengiz, S., Pala, R., \& Dundar, A. (2013). Effect of Football Practices on Certain Blood Values of Athletes, Advances in Environmental Biology, 7(5), 924-927.

Ferrauti, A, Maier, P., \& Weber, K. (2002). Tennistraining, Meyer and Meyer Verlag.

Gencer, Y. G., Coskun, F., Sarikaya, M., \& Kaplan, S. (2018). Investigation on the Effects of 12 Days Intensive Competition on Some Blood Parameters of Basketball Players. Journal of Education and Training Studies, 6(4), 79-83. https://doi.org/10.11114/jets.v6i4.3011

Gullikson, T. (2003). Teniste Fiziksel Uygunluk Testleri (Çev. Yavuz Yarsuvat B.), Spor Araştırmaları Dergisi, 7(1), 135-156.

Hoare, D. G. (2000). Predicting success in junior elite basketball players the contribution of anthropometic and physiological attributes, Sci. Med. Sport., 3(4), 39-405. https://doi.org/10.1016/S1440-2440(00)80006-7

Ibis, S., Hazar, S., \& Gokdemir, K. (2010). Acute Effect of Hematological Parameters on Aerobic and Anaerobic Exercise, Journal of Human Sciences, 7(1).

Kermen, O. (1997). Tenis Teknik ve Taktikleri, Asama Matbaacilik, İstanbul.

Nieman, D. C., \& Pedersen, B. K. (1999). Exercise and Immune Function: Recent Development. Sports Medicine, 27, 73-80. https://doi.org/10.2165/00007256-199927020-00001

Novosadova, J. (1977). The Changes in Hematocrit, Hemoglobin, Plasma Volume and Proteins During and After Different Types of Exercise, European Journal of Applied Physiology and Occupational Physiology, 36(3), 223230. https://doi.org/10.1007/BF00421753

Ölçücü, B., Canikli, A., Hadi, H., \& Taşmektepligil, M. (2012). Physıcal and Physılogıcal Characterıstıcs of 12 - 14 Age Categories Female Tennis Players Y., Journal of Sports and Performance Researches, 3(1).

Özer, Y., Bozdal, Ö., \& Pancar, Z. (2017). Acute Effect of Circuit Aerobıc And Traditional Aerobıc Trainıng on Hamstring Flexibility In Sedentary Women. European Journal Of Physical Education and Sport Science. 3(12), 268-275.

Pancar, Z. Effect of 8-Week Plyometric Trainıng on Selected Strength Parameters of 12-14 Aged Woman Handball Players. Gaziantep University Health Sciences Institute, Graduate thesis, Gaziantep.

Pancar, Z., Biçer, M., \& Özdal, M. (2018). Effect of 8-Week Plyometrıc Traınıng on Selected Strength Parameters of 12-14 Aged Woman Handball Players. Journal of Sports and Performance Researches, 9(1), 18-24.

Pancar, Z., Bozdal, Ö., Biçer, M., \& Akcan, F. (2017). Acute Effect of Anaerobıc Exercıse on Dynamıc Balance of Sedentary Young Boys. European Journal Of Physical Education and Sport Science, 3(12), 229-237.

Pancar, Z., Özdal, M., \& Çınar, V. (2017). The Effect Of 4-Weekly Low Intensity Physıcal Actıvıty Program In Thyro1d Hormone Levels In Obese And Overwe1ght Children. European Journal of Physical Education and Sport Science, 3(11), 1-8.

Pancar, Z., Özdal, M., Pancar, S., \& Biçer, M. (2016). Investıgatıon of Visual And Auditory Simple Reactıon Time of 11-18 Aged Youth. . European Journal of Physical Education and Sport Science, 2(4), 145-152.

Pancar, Z., Özdal, M., Sarıkaya, M., \& Çınar, V. (2018). Effect of Physical Activity Program on Iron and Iron-Binding Capacity in Obese Children. Scholars Journal of Arts, Humanities and Social Sciences, 6(6), 1299-1303.

Selçuk, M., Aslan, T. V., Temur, H. B., \& Çınar, V. (2018). The Healıng Effect of Football Traınıngs on Lıpıd Profıle and Muscle Damage Markers in 11-13 Years Old Boys. Journal of Sports and Performance Researches, 9(1), 44-49.

Vural, M., Özdal, M., \& Öztütüncü, S. (2017). The Effect of 4-Week Two Different Strength Traınıng Programs on Body Composition. European Journal of Physical Education and Sport Science, 3(7), 1-10.

Weber, K. (1982). Tenis-Fitness, BLV Verlagsgesellschaft.

Zorba, E. (1993). Herkes İcin Spor ve Fiziksel Uygunluk, GSGM Yayinları, Ankara.

\section{Copyrights}

Copyright for this article is retained by the author(s), with first publication rights granted to the journal.

This is an open-access article distributed under the terms and conditions of the Creative Commons Attribution license which permits unrestricted use, distribution, and reproduction in any medium, provided the original work is properly cited. 